\begin{tabular}{|c|c|c|}
\hline \multirow{3}{*}{$\begin{array}{r}\text { Case Reports in } \\
\text { Gastroenterology }\end{array}$} & \multirow{2}{*}{\multicolumn{2}{|c|}{ Case Rep Gastroenterol 2015;9:49-55 }} \\
\hline & & \\
\hline & $\begin{array}{l}\text { DOI: 10.1159/000368115 } \\
\text { Publisned online: February 10, } 2015\end{array}$ & $\begin{array}{l}\text { ( ) } 2015 \text { S. Karger AG, Basel } \\
1662-0631 / 15 / 0091-0049 \$ 39.50 / 0 \\
\text { www.karger.com/crg }\end{array}$ \\
\hline & \multicolumn{2}{|c|}{$\begin{array}{l}\text { This is an Open Access article licensed under the terms of the Creative Commons } \\
\text { Attribution-NonCommercial } 3.0 \text { Unported license (CC BY-NC) (www.karger.com/OA } \\
\text { license), applicable to the online version of the article only. Distribution permitted for non } \\
\text { commercial purposes only. }\end{array}$} \\
\hline
\end{tabular}

\title{
Age Is No Longer a Limit: Two Cases of Hepatectomy in Patients Over 90 Years Old
}

\author{
Shugo Uwatoko ${ }^{\text {a }}$ Kentaroh Yamamoto ${ }^{a}$ Takamitsu Sasaki $^{\text {b }}$ \\ Daisuke Fukumori $^{c}$ Hirotsune Igimi $^{\mathrm{a}}$ Mami Yamamoto $^{\mathrm{a}}$ \\ Fumio Yamamoto ${ }^{a}$ Yuichi Yamashita ${ }^{b}$ \\ ${ }^{a}$ Department of Surgery, Yamamoto Memorial Hospital, Imari, and ${ }^{b}$ Department of \\ Gastroenterological Surgery, Fukuoka University School of Medicine, Fukuoka, Japan; \\ 'Department of Surgery, Rigs Hospital, Copenhagen, Denmark
}

\section{Key Words}

Hepatocellular carcinoma $\cdot$ Elderly patients

\begin{abstract}
Hepatocellular carcinoma (HCC) is a common malignant tumor with poor prognosis. The age of patients affected by HCC is considered to be increasing, and several studies have reported significantly higher rates of morbidity and mortality after hepatectomy for HCC in elderly patients. However, other studies have reported that the short- and long-term outcomes of surgery for HCC in elderly patients are similar to those in younger patients. Whether the indications for hepatic resection in elderly patients resemble those in younger patients has thus been questioned. We describe two cases of patients over 90 years old who underwent major hepatectomy for HCC, representing the oldest patients in the world to have done so.
\end{abstract}

(C) 2015 S. Karger AG, Basel

\section{Introduction}

Mean life expectancy has been increasing in many countries, and the management of malignancies in the elderly has thus become a global issue [1-3]. Hepatocellular carcinoma (HCC) is a common malignant tumor with poor prognosis, and the numbers of elderly patients with HCC are expected to increase around the world [4]. 
Uwatoko et al.: Age Is No Longer a Limit: Two Cases of Hepatectomy in Patients Over 90 Years Old

Several studies in the 1990s and early 2000s reported significantly higher rates of morbidity and mortality after hepatectomy in elderly patients [5-8]. On the other hand, recent studies have found that the short- and long-term outcomes of hepatectomy in elderly patients are similar to those in younger patients [4, 9-12]. The indications for hepatic resection in elderly patients have been questioned, and given the increasing number of affected elderly patients, this issue requires serious consideration. We report herein two cases of successful hepatectomy in patients over 90 years old.

\section{Case Reports}

Case 1

The patient was a 91-year-old man. He underwent a medical examination for hypertension and chronic atrial fibrillation, during which a mass was palpated through the abdominal wall. He was then referred to our hospital. Laboratory data were as follows: aspartate aminotransferase (AST) $61 \mathrm{IU} / \mathrm{l}$ (normal 5-35), alanine aminotransferase (ALT) 37 IU/l (normal 5-30), alkaline phosphatase (ALP) $334 \mathrm{U} / \mathrm{l}$ (normal 115-359), gamma-glutamyl transferase ( $\gamma$-GTP) 230 IU/l (normal 0-50), lactate dehydrogenase (LDH) 177 IU/l (normal 106-211), albumin (Alb) $3.6 \mathrm{~g} / \mathrm{dl}$ (normal 3.7-5.5), total bilirubin (TB) $0.71 \mathrm{mg} / \mathrm{dl}$ (normal 0.2-1.0), and prothrombin time-international normalized ratio (PT-INR) 1.03. Child-Turcotte-Pugh grade was A. The indocyanine green retention rate at 15 min (ICG-R15) was $8 \%$. The concentration of serum alpha-fetoprotein (AFP) was 3,600 ng/ml (normal <20) and plasma des- $\gamma$-carboxy prothrombin (DCP), also known as protein induced by vitamin K deficiency or antagonist-II, was 93,300 mAU/ml (normal <40). No serological evidence of hepatitis B or $\mathrm{C}$ was seen. Contrast-enhanced computed tomography (CECT) revealed a tumor measuring $78 \mathrm{~mm}$ in diameter in the left lateral sector of the liver (fig. 1). HCC was suspected. The patient requested radical surgery, so left lateral sectorectomy was performed (fig. 2). The operation time was $370 \mathrm{~min}$, and the amount of blood loss was $978 \mathrm{ml}$. Pathological findings revealed well to moderately differentiated HCC (fig. 3).

Case 2

The patient was a 91-year-old woman. Laboratory data were as follows: AST 35 IU/l (normal 5-35), ALT 21 IU/l (normal 5-30), ALP 198 U/l (normal 115-359), $\gamma$-GTP 67 IU/l (normal 0-50), LDH $162 \mathrm{IU} / \mathrm{l}$ (normal 106-211), Alb $2.9 \mathrm{~g} / \mathrm{dl}$ (normal 3.7-5.5), TB $0.7 \mathrm{mg} / \mathrm{dl}$ (normal 0.2-1.0), and PT-INR 1.18. Child-Turcotte-Pugh grade was A. The ICG-R15 was $19 \%$. The concentration of serum AFP was $1,210 \mathrm{ng} / \mathrm{ml}$ (normal <20) and plasma DCP was $209 \mathrm{mAU} / \mathrm{ml}$ (normal $<40$ ). No serological evidence of hepatitis B or C was seen. CECT revealed a tumor measuring $20 \mathrm{~mm}$ in diameter in segment 2 of the liver, accompanied by tumor thrombi toward the main left portal vein (fig. 4). We diagnosed HCC with tumor thrombi. The patient requested radical surgery, so left hemi-hepatectomy was performed (fig. 5). The operation time was $304 \mathrm{~min}$, and the amount of blood loss was $379 \mathrm{ml}$. Pathological findings revealed poorly differentiated HCC (fig. 6).

\section{Discussion}

HCC is a common malignant tumor with poor prognosis. Mean life expectancy has been increasing in many countries, and the management of malignancy in the elderly has become a global issue [1-3]. Aging is associated with gradual decreases in liver volume and blood 
Uwatoko et al.: Age Is No Longer a Limit: Two Cases of Hepatectomy in Patients Over 90 Years Old

flow [13]. General markers of liver function, such as levels of AST, ALT, serum TB and ALP, are largely unaffected by aging [14]. In contrast, decreases are seen in serum levels of Alb, some amino acids and some coagulation factors, including fibrinogen, prothrombin and thromboplastin [15]. Several studies in old rodents have suggested that aging compromises the regenerative capacity of the liver after hepatectomy or ligation of the portal vein $[16,17]$. Advanced age is already a high risk factor for staying alive [18], and the risks associated with surgical treatment are thus considered to be further magnified. Furthermore, advanced age increases complications such as high blood pressure and diabetes mellitus.

In recent years, hepatectomy for much more elderly patients has been attracting increasing attention. Several studies in the 1990s and early 2000 s reported significantly higher rates of morbidity and mortality in elderly patients [5-8]. On the other hand, recent studies have reported the safety of surgery in elderly patients [4, 9-12]. The age standards for hepatectomy are rising because hepatectomy is being performed with increasing safety. After stringent criteria for hepatectomy were proposed, the mortality rate decreased markedly [19]. With the development of surgical energy devices, such as vessel-sealing instruments and ultrasonic surgical devices, surgical procedures have become easier than ever before [20]. Furthermore, in recent years, the laparoscope for hepatectomy has been attracting attention as a means to reduce surgical stress [21]. Such developments are contributing to the increasing use of hepatectomy and the increasing standard age of recipients. However, the optimal age limits remain unclear. In our department, we place emphasis on anesthetic procedures to reduce surgical stress. We perform hepatectomy solely under epidural anesthesia, avoiding general anesthesia (fig. 7) [22]. By avoiding overly stressful surgery in this manner, we have been able to perform major hepatectomy in patients over 90 years old with no postoperative complications.

Here, we reported two cases of successful treatment for patients over 90 years old, and our cases represent the oldest cases yet described to have undergone major hepatectomy. We think hepatectomy offers survival benefits for carefully selected elderly patients. Case 2 remarked that elderly patients who were afraid of undergoing surgery at her age could be encouraged by her results. We want to emphasize that age is no longer a limit for hepatectomy.

\section{References}

1 Colapinoto ND: Is age alone a contraindication to major cancer surgery? Can J Surg 1985;28:323-326.

2 McKenna RJ Sr: Clinical aspects of cancer in the elderly. Treatment decisions, treatment choices, and follow-up. Cancer 1994;74(7 suppl):2107-2117.

-3 Monfaridini S, Aapro M, Ferrucci L, Zagonel V, Scalliet P, Fentiman I: Commission of the European Communities 'Europe Against Cancer' Programme. European school of oncology advisory report. Cancer treatment in the elderly. Eur J Cancer 1993;29A:2325-2330.

4 Kaibori M, Matsui K, Ishizaki M, Saito T, Kitade H, Matsui Y, Kwon AH: Hepatic resection for hepatocellular carcinoma in the elderly. J Surg Oncol 2009;99:154-160.

-5 Lui WY, Chau GY, Wu CW, King KL: Surgical resection of hepatocellular carcinoma in elderly cirrhotic patients. Hepatogastroenterology 1999;46:640-645.

-6 Yamamoto K, Takenaka K, Matsumata T, Shimada M, Itasaka H, Shirabe K, Sugimachi K: Right hepatic lobectomy in elderly patients with hepatocellular carcinoma. Hepatogastroenterology 1997;44:514-518.

-7 Takenaka K, Shimada M, Higashi H, Adachi E, Nishizaki T, Yanaga K, Matsumata T, Ikeda T, Sugimachi K: Liver resection for hepatocellular carcinoma in the elderly. Arch Surg 1994;129:846-859.

-8 Cescon M, Grazi GL, Del Gaudio M, Ercolani G, Ravaioli M, Nardo B, Cavallari A: Outcome of right hepatectomies in patients older than 70 years. Arch Surg 2003;138:547-552.

-9 Ferrero A, Viganò L, Polastri R, Ribero D, Lo Tesoriere R, Muratore A, Capussotti L: Hepatectomy as treatment of choice for hepatocellular carcinoma in elderly cirrhotic patients. World J Surg 2005;29: 1101-1105. 


\section{Case Reports in \\ Gastroenterology}

\begin{tabular}{l|l}
\hline \multicolumn{2}{l}{ Case Rep Gastroenterol 2015;9:49-55 } \\
\hline DOI: 10.1159/000368115 & $\begin{array}{l}\text { @ } 2015 \text { S. Karger AG, Basel } \\
\text { www.karger.com/crg }\end{array}$ \\
\hline
\end{tabular}

Uwatoko et al.: Age Is No Longer a Limit: Two Cases of Hepatectomy in Patients Over 90 Years Old

10 Kondo K, Chijiiwa K, Funagayama M, Kai M, Otani K, Ohuchida J: Hepatic resection is justified for elderly patients with hepatocellular carcinoma. World J Surg 2008;32:2223-2229.

11 Tsujita E, Utsnomiya T, Ohta M, Tagawa T, Matsuyama A, Okazaki J, Yamamoto M, Tsutsui S, Ishida T: Outcome of repeat hepatectomy in patients with hepatocellular carcinoma aged 75 years and older. Surgery 2010;147:696-703.

12 Yamada S, Shimada M, Miyake H, Utsunomiya T, Morine Y, Imura S, Ikemoto T, Mori H, Hanaoka J, Iwahashi S, Saito Y: Outcome of hepatectomy in super-elderly patients with hepatocellular carcinoma. Hepatol Res 2012;42:454-458.

-13 Wynne HA, Cope LH, Mutch E, Rawlins MD, Woodhouse KW, James OF: The effect of age upon liver volume and apparent liver blood flow in healthy man. Hepatology 1989;9:297-301.

14 Taniai N, Yoshida H, Yoshioka M, Kawano Y, Uchida E: Surgical outcomes and prognostic factors in elderly patients with hepatocellular carcinoma who underwent hepatectomy. J Nippon Med Sch 2013;80:426-432.

15 Gamgert SR, Tsitorus PD, Duthie EH Jr: Interpretation of laboratory results in the elderly. 2. A clinician's guide to endocrine tests. Postgrad Med 1982;72:251-256.

16 Schmucker DL, Sanchez H: Liver regeneration and aging: a current perspective. Curr Gerontol Geriatr Res 1998;53:315-320.

17 Timchenko NA: Aging and liver regeneration. Trends Endocrinol Metab 2009;20:171-176.

18 Olesen JB, Lip GY, Hansen ML, Hansen PR, Tolstrup JS, Lindhardsen J, Selmer C, Ahlehoff O, Olsen AM, Gislason GH, Torp-Pedersen C: Validation of risk stratification schemes for predicting stroke and thromboembolism in patients with atrial fibrillation: nationwide cohort study. BMJ 2011;342:d124.

19 Imamura H, Seyama Y, Kokudo N, Maema A, Sugawara Y, Sano K, Takayama T, Makuuchi M: One thousand fifty-six hepatectomies without mortality in 8 years. Arch Surg 2003;138:1198-1206; discussion 1206.

20 Doklestic K, Karamarkovic A, Stefanovic B, Stefanovic B, Milic N, Gregoric P, Djukic V, Bajec D: The efficacy of three transection techniques of the liver resection: a randomized clinical trial. Hepatogastroenterology 2012;59:1501-1506.

21 Ishizawa T, Gumbs AA, Kokudo N, Gayet B: Laparoscopic segmentectomy of the liver: from segment I to VIII. Ann Surg 2012;256:959-964.

22 Yamamoto K, Fukumori D, Yamamoto F, Yamamoto M, Igimi H, Yamashita Y: First report of hepatectomy without endotracheal general anesthesia. J Am Coll Surg 2013;216:908-914.

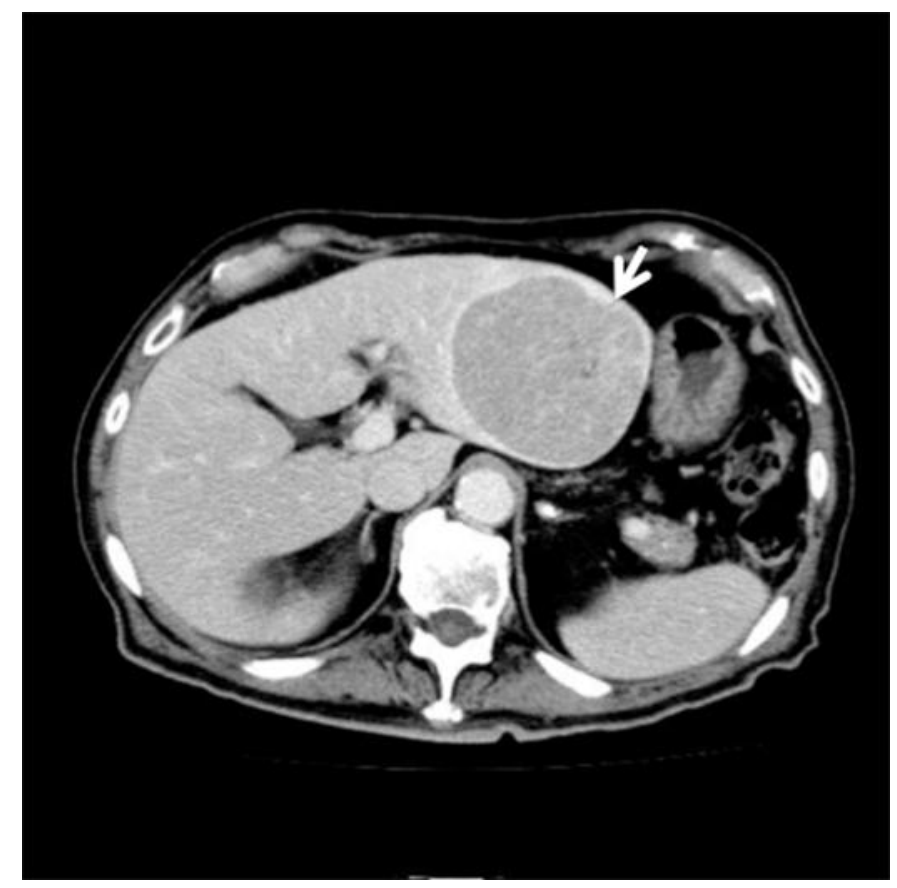

Fig. 1. CECT. The arrow shows a tumor measuring $78 \mathrm{~mm}$ in diameter in the left lateral sector of the liver. 


\begin{tabular}{ll|l} 
Case Reports in & \multicolumn{2}{l}{ Case Rep Gastroenterol 2015;9:49-55 } \\
\cline { 2 - 3 } Gastroenterology & $\begin{array}{l}\text { DOI: } 10.1159 / 000368115 \\
\text { www.karger.com/crg }\end{array}$ \\
\cline { 2 - 3 } & Uwatoko et al.: Age Is No Longer a Limit: Two Cases of Hepatectomy in Patients Over
\end{tabular}
90 Years Old

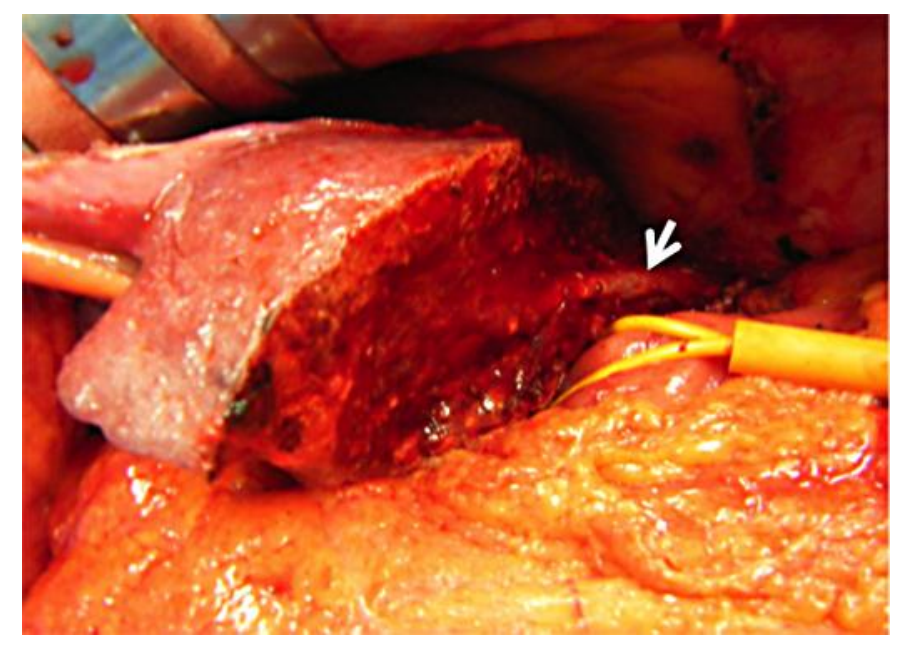

Fig. 2. Postoperative view. The arrow shows the left hepatic vein exposed at the cut surface of the liver.

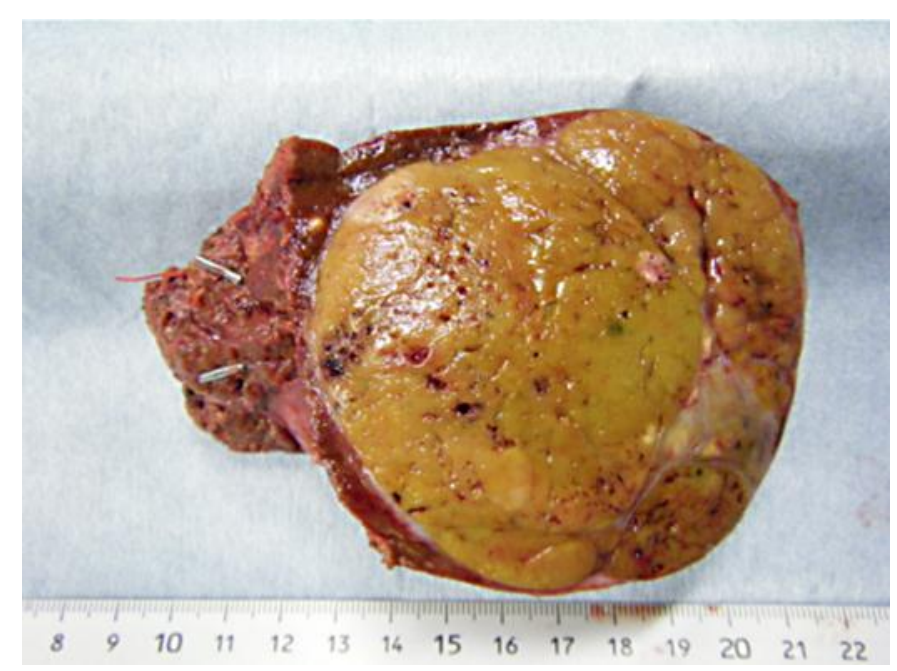

Fig. 3. The resected specimen. Pathological examination showed well to moderately differentiated HCC. 


\begin{tabular}{ll|l} 
Case Reports in & \multicolumn{2}{l}{} \\
\cline { 2 - 3 } Gastroenterology & Case Rep Gastroenterol 2015;9:49-55 & $\begin{array}{l}\text { ○ 2015 S. Karger AG, Basel } \\
\text { www.karger.com/crg }\end{array}$ \\
\cline { 2 - 3 } & DOI: 10.1159/000368115 & Uwatoko et al.: Age Is No Longer a Limit: Two Cases of Hepatectomy in Patients Over
\end{tabular}
90 Years Old

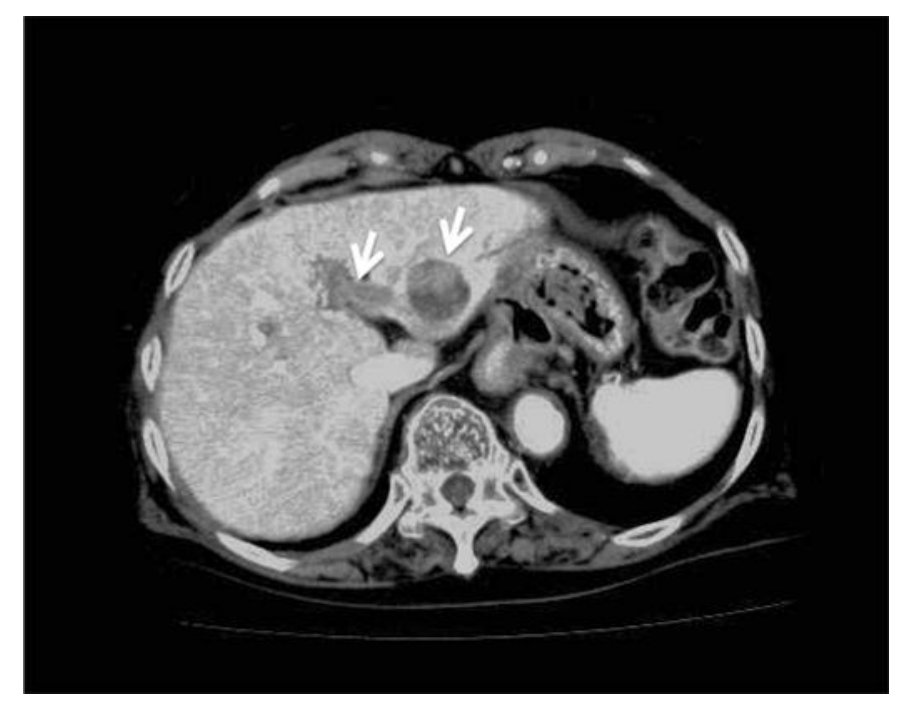

Fig. 4. CECT. The arrows show a tumor measuring $20 \mathrm{~mm}$ in diameter in segment 2 of the liver, accompanied by tumor thrombi toward the main left portal vein.

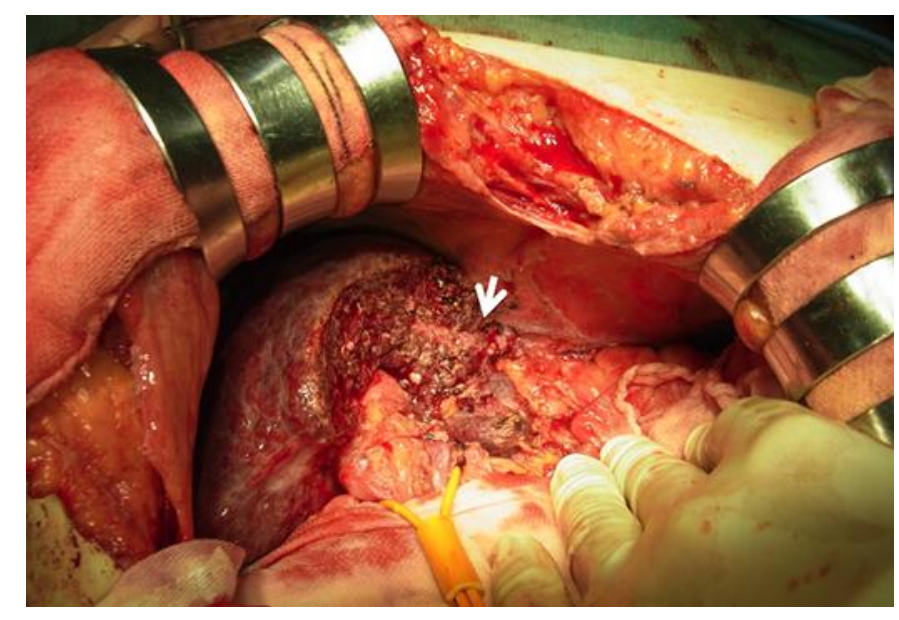

Fig. 5. Postoperative view. The arrow shows the middle hepatic vein exposed the cut surface of the liver. 
Uwatoko et al:: Age Is No Longer a Limit: Two Cases of Hepatectomy in Patients Over 90 Years Old

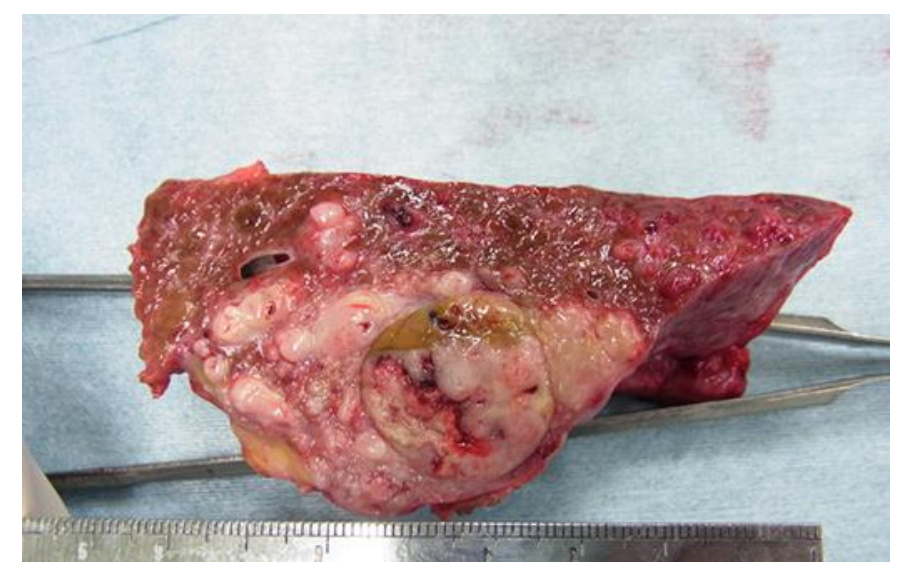

Fig. 6. The resected specimen. Pathological examination showed poorly differentiated HCC.

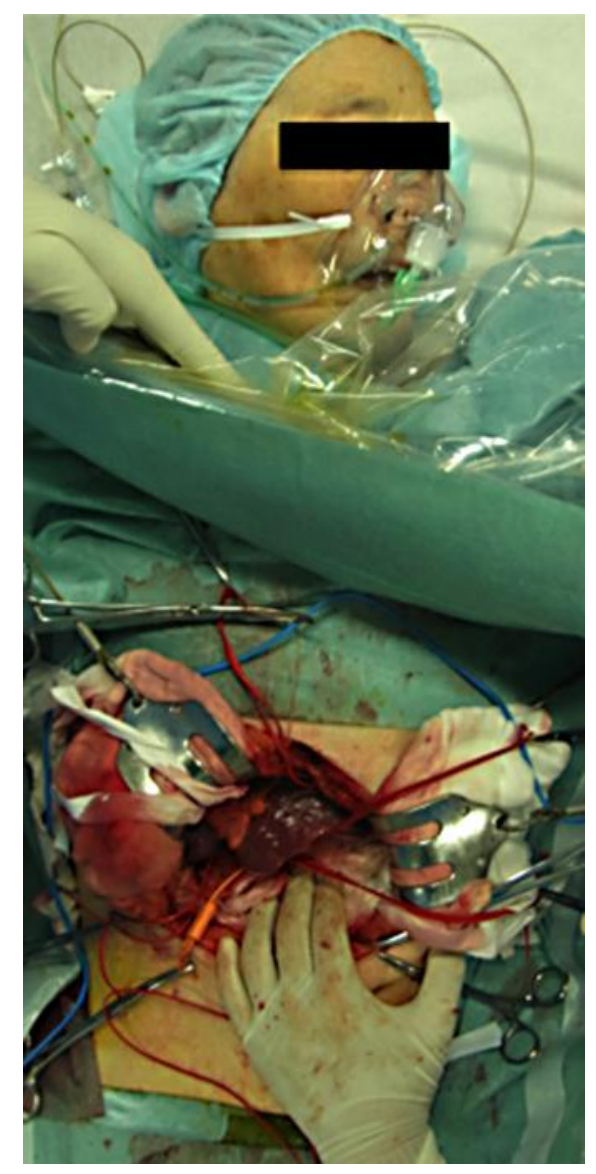

Fig. 7. Hepatectomy without endotracheal general anesthesia. 